\title{
Social Life as Collective Struggle: Closure Theory and the Problem of Solidarity
}

\author{
Jürgen MACKERT ${ }^{1}$
}

University of Potsdam

\begin{abstract}
In recent years, all over the globe we have seen intensifying economic exploitation, political disenfranchisement, social marginalization and cultural repression in all kinds of political regimes, from liberal democratic to authoritarian and dictatorial. Although the strategies vary with regard to regime and context, in all of them we observe that while a growing number of social groups are speaking out and rising against them, a presumably much higher number of groups do not. In this article, I argue that all these processes can be conceived as aspects of ongoing closure struggles in social life. However, in order to understand why some social groups are able to fight against closure strategies while others are not, closure theory in its current state of elaboration is not of any help. While it operates with the term solidarization, it does not offer any explanation of how such acting in solidarity may become possible in closure struggles. The article is a mainly theoretical contribution of how to solve this problem.
\end{abstract}

Keywords: social closure, struggle, solidarization, democracy

\section{Introduction}

In recent years, in various regimes from liberal-democratic to authoritarian and dictatorial ones, we have seen a growing number of social groups speaking out and rising against their economic exploitation, political disenfranchisement, social marginalization and cultural repression. In fact, all over the globe, economic, social and political, ethnic, religious, language, gender and indigenous groups have been the targets of governments' and powerful groups' strategies to deprive them of rights or prevent them from accessing resources and other options that human beings need to survive and to participate in public, politics, and culture. As different as the various regimes are, to be sure so are the strategies pursued in them by governments or powerful social groups. However, what they all have in common is that all these strategies have

\footnotetext{
${ }^{1}$ Jürgen Mackert is a professor of sociology at the Faculty of Economics and Social Sciences at the University of Potsdam (juergen.mackert@uni-potsdam.de).
} 
deep impacts on the life chances of the targeted groups. Given this situation, we should work on sociological perspectives to approach these problems within a convincing theoretical and analytical frame.

I argue that in principle all social phenomena of an intensified struggle for life chances can be conceived of as closure struggles and should therefore be analyzed against the background of social closure theory. Yet at the same time, closure theory is fraught with critical problems that have to be solved by fundamentally re-conceptualizing it in order to actually offer a theoretical and analytical framework to allow for analyzing the various phenomena referring to the denial of political, economic, social and cultural participation. While this task of course goes beyond the scope of a single article, here I deal with one aspect of this comprehensive endeavor by concentrating on the problem of why closure theory has not been able to address properly a critical question that has become very clear in the face of intensified closure struggles: How can we make sense of the fact that in recent years all over the world and in very different regimes and contexts a substantial number of social groups has succeeded in confronting their being exploited, disenfranchised, marginalized and repressed by demonstrating, resisting, rebelling or rioting, while no fewer people have not? If we want to know why in closure struggles some groups counteract while others do not, the theory of social closure is not of great help and has to be elaborated. In this article, in order to start the project of revising closure theory I reconsider basic concepts and ideas of closure theory and suggest replacing the unsatisfying discussion of processes of solidarization with looking at processes of a formation of political identities that necessarily precede any idea of a kind of acting in solidarity.

The article proceeds with first giving an impression of what I describe as closure struggles by discussing various examples of varying possibility of social actors to fight back against strategies of social closure as collective actors. Second, I follow Max Weber's dictum to conceive of social life as struggle in order to discuss all these struggles, be they successful or not, in a dynamic and processual perspective. Third, I point to a critical lacuna in closure theory that has not taken into consideration critical processes of group formation and collective action. Therefore in a fourth step, rather than sticking to an unclear idea of solidarity, I suggest concentrating on analyzing processes of the construction of political identities that, if successful, allow to understand what enables social groups to act in closure struggles. Finally, against this background I argue that closure theory cannot restrict itself to looking at how social groups are excluded from rights and resources but also needs to take into consideration how the strategies of powerful groups impinge upon social groups' ability to develop political identities to keep these groups powerless and dependent, leaving them in weak positions in today's struggles for democracy, security, rights, resources and a life in dignity.

\section{Regimes and Contexts: The Many Faces of a Politics of Closure}

In briefly referring to various strategies of closure in different regions in the world pursued by governments and/or powerful social groups, I make a plea for a broad conception of social closure that goes far beyond the narrow conception of closure theory as a so-called "monopoly 
paradigm" (Silver 1994). ${ }^{2}$ Instead of thinking about social closure in terms of simply monopolizing resources, I argue in favor of a broad approach to social closure, looking at the manifold ways of processes of economic exploitation, political disenfranchisement, social marginalization and cultural repression that have a deep impact on social actors' life chances.

\section{Fighting Back...}

The movement of the gilets jaunes in France since 2018, the uprising against the authoritarian neo-liberal regime in Chile in 2019/20, the demonstrations against mass impoverishment in Argentina since 2019, the fight against the consequences of the troika's democratically not legitimated austerity diktat in Greece as well as many other demonstrations and riots in recent years are reactions against the consequences of a neoliberal politics of marketization, privatization, and individualization of social security, health, education, or pensions that have marginalized citizens and curtailed their social rights and access to resources.

All these counterstrategies of citizens oppose their exclusion in an ongoing global class war. As billionaire Warren Buffett has put this very bluntly: "There's class warfare, all right, [...] but it's my class, the rich class, that's making war, and we're winning" (Stein 2006). Austerity politics following the banking crisis in 2008 cut deep into public services and have heavily damaged many public services. The global coronavirus pandemic has dramatically revealed the fatal consequences of neoliberal elites and powerful oligarchies once again having put Profit over People (Chomsky 1999). Their decades-long fight against public services such as public health services in the end has proved to be a lethal fight. By marketizing and privatizing it, pursuing strategies to reduce bed capacities, including intensive care beds, and reducing employees in order to gain profits, they have deliberately put at risk the lives of citizens, leading to the death of hundreds of thousands of people (World Bank 2020).

In both authoritarian regimes and liberal democracies, social groups and movements fight for their rights in a new cultural war that these regimes have unleashed. Women's groups oppose the propagated ideal of traditional (Christian) family values and the destruction of their reproductive rights as in Poland (AFP 2021), refusing to accept a subordinated role for women and defending their reproductive rights. LGBTQ groups demand the end of discrimination and to be fully accepted in society, while solidarity movements support migrants who are confronted manifold ways of processes of economic exploitation, political disenfranchisement, social marginalization and cultural repression that have a deep impact on social actors' life chances. Great liberal minds such as John Stuart Mill or Aléxis de Tocqueville, firmly standing in the Judeo-Christian tradition, opened Pandora's box to let all the ingredients of White racial supremacism out into the world (Losurdo, 2014; Mamdani, 2015 Mills, 1997; cf. Mackert, 2021).

In the MENA (Middle East and North Africa) region, we see the Algerian hirak, which is the supposedly largest and longest lasting peaceful demonstration ever in favor of democracy, fighting against a ruthless and corrupt regime by going back to its cultural traditions to create specific new forms of resistance in an Arab society (Northey 2021; Ottaway \& Ottaway 2020). The common demands of a huge plurality of social groups for political rights and democratic

\footnotetext{
${ }^{2}$ I cannot go into a detailed discussion here about this misconception of closure theory that, unfortunately, is due to a narrow idea of closure in the theory of social closure itself.
} 
participation is a rather unexpected example of a population fighting back after it has been excluded from political decision-making for decades.

In countries such as the USA and Canada, movements of indigenous people standing up for their inalienable rights (Bracken 2020; Langer 2020) make obvious the murderous history of White Christian and liberal settler colonial states that established settler democracies for the White occupiers which until today exclude the original population from citizenship rights, resources and so forth, threatening them with eliminatory politics (Wolfe 2006; Veracini 2013; Lloyd 2012). No less, so does the Black Lives Matter movement (Loyd \& Bonds 2018) that has dramatically revealed the USA's tradition as a racist and supremacist slaveholder society (Mann 2005) that until today represses the Black population with racial profiling thorough surveillance, mass incarceration, and even voter suppression, to name only a few of the radical closure strategies against the Black population in the self-declared Greatest Democracy in the World. ${ }^{3}$ This list of social groups and movements standing up against various facets of such politics of closure and fighting back being pushed aside or forced to live at the fringes of society could easily be extended. However, in contrast to these groups, there are huge numbers of people who have not succeeded or not yet succeeded in fighting back by organizing their groups.

\section{... And Not Fighting Back}

During the last decades and especially after the banking crisis in 2008, the global neoliberal rationality has created a politico-economic regime that has already pushed considerable parts of the populations to the edge, destroying the life chances of social groups such as the older people, the (chronically) sick, the poor, single mother households, disabled persons in almost every society in the West, all of whom are hardly able to fight back against these closure strategies. High insecurity, poverty risk and a radical minimization of chances to survive have been created for migrants, asylum seekers, and persons without papers. Such strategies are obvious in the case of the European Union's migration regime that is nothing but a radical regime of social closure that has transformed the Mediterranean into a mass grave where those it aims to keep at a distance from its borders are dying while being observed by drones (Ahmed 2020). Further, the EU's cynical agreements with regimes in Africa have relocated the borders of its politics of closure against refugees into African countries, and the EU pays them well to stop refugees from travelling though their territories knowing very well that these refugees are in severe danger of being put in concentration camps, being enslaved, tortured, and killed (Plaut 2017). But also on its own territory, the so-called Union of Values pursues strategies of social closure that have led to disastrous living conditions in refugee camps on Greek islands (Fallon 2021) or to working conditions for refugees that can only be called a new slavery (Patterson \& Zhuo 2018). The new European slavery takes many different forms, from human trafficking and forced labor (Abellan Matamoros 2019) to the tens of thousands of modern slaves working

\footnotetext{
${ }^{3}$ It is well known that most of the celebrated Founding Fathers of the US were landowners and slaveholders and outspoken with regard to genocide if necessary. Having invaded the land, Thomas Jefferson made this explicit: "If ever we are constrained to lift the hatchet against any tribe, we shall never lay it down till that tribe is exterminated, or driven beyond the Mississippi. [...] In war, they will kill some of us; we shall destroy all of them. (Thomas Jefferson, cited in Mann 2005: 70)
} 
in the south of Spain or Italy, picking food for privileged EU citizens under degrading and dehumanizing conditions (de Pablo, Zurita, Kelly \& Carlile 2020).

In Palestine, the occupying Israeli forces, with full support of the Palestinian Authority (PA), repress civil society activities of Palestinians (Baumgarten 2021; Burkert 2021), restrict NGO's possibilities (Muaddi 2021) and incarcerate Palestinian political and intellectual leaders (Masarwa \& Akkad 2017). Further, China has violently destroyed the democracy movement in Hong Kong (Roth 2020), now convicting its representatives and supporters, while Russia suppresses critical voices who demand any democratization of the autocratic system and an end corruption (DW 2021).

This list could also be considerably extended, yet in contrast to the former cases these people and social groups targeted by strategies of social closure are hardly able to fight back, if at all. Interestingly, very often even within one society some social groups are able to collectively act when threatened and confronted with exclusionary strategies while others cannot. Why is that the case? How can we make sense of these differences in permanent struggles of social closure? Turning to closure theory in order to answer such questions, in a first step, I argue we have to take basic ideas of Max Weber more seriously than the tradition of the theory of social closure has done.

\section{Social Life as Struggle - the Weberian Legacy of Closure}

Social closure is one of the most basic ideas in sociology. Max Weber introduced it as one of the basic terms in Economy and Society as open and closed social relationships (\$10). Putting this basic term into context makes immediately clear that this term does not accidentally stand in immediate proximity to two other basic concepts, namely struggle (\$8) and communal and associative social relationships (\$9) (Weber [1922] 2012: 38-46). ${ }^{4}$ In The Meaning of 'Value Freedom' in the Sociological and Economic Sciences, Weber argues that social life has to be conceived of as struggle as he was convinced "that [struggle] is an ineradicable element of all cultural life" (Weber [1922] 2012: 320). ${ }^{5}$ Of course, Weber developed this perspective against the background of World War I and was influenced by Friedrich Nietzsche and Charles Darwin, yet I argue, as Pierre Bourdieu did following Weber, that struggle is the very basis of social life, ascribing to it an ontological status. We simply cannot assume social life to express some broad consensus or peaceful proceeding; rather, the logic and dynamics of society are characterized by social struggles (Müller 2007: 119). Social actors - individual and collective - in their daily lives are confronted with opponents, competitors, even enemies in struggles for life chances. In such struggles, the powerful side tries to keep the less powerful from scarce resources, rights, or positions. Based on this general perspective on social life, Weber's approach to the social world opens a socio-theoretical perspective that allows us to understand social life also as an ongoing closure struggle for life chances that social actors are fighting with peaceful or violent means and that

\footnotetext{
${ }^{4}$ Unfortunately, parts of the English translation of Wirtschaft und Gesellschaft are simply false. The original German term Kampf means struggle and it is utterly misleading to translate it as conflict.

${ }^{5}$ In The Meaning of 'Value Freedom' in the Sociological and Economic Sciences, the German term Kampf is also falsely translated as conflict. Here again, I translate it as struggle.
} 
cannot be terminated. At the same time, this approach allows for a highly differentiated view of various dimensions, processes and degrees of social closure. In this sense, struggles turn out to be critical in order to understand any human sociation (Georg Simmel), which Weber approaches by introducing an ideal-typical differentiation between communal and associative social relationships ( $\$ 9)$. The purest forms of associative relationships are market exchange, the purely voluntary goal-oriented association pursuing objective (economic or other) interests, and a voluntary value-oriented association. In contrast, the purest forms of communal relationships are religious groups, comradeship and the family, all acting affectually or traditionally motivated.

A social relationship will be called 'communal' (Vergemeinschaftung) if and so far as the orientation of social action - whether in the individual case, on the average, or in the pure type - is based on a subjective feeling of the parties, whether affectual or traditional, that they belong together. A social relationship will be called 'associative' (Vergesellschaftung) if and insofar as the orientation of social action rests on a rationally motivated adjustment of interests or a similarly motivated agreement, whether the basis of rational judgement be absolute values or reasons of expediency (Weber [1922] 1978: 40-41).

This differentiation is crucial, but it does not conceive of communal relationships as solely harmonious and inclusive while associative relationships point to ever-enduring struggles. Rather, Weber argues that although communal relationship and struggle seem to be radically opposed, "coercion of all sorts is a very common thing in even the most intimate of such communal relationships if one party is weaker than the other" (Weber [1922] 1978: 42). Therefore, each "[struggle] varies enormously according to the means (violent or 'peaceful') and how ruthlessly they are employed" (Weber [1922] 1978: 42).

Against the background of conceiving of social life as struggle and by distinguishing between types of social relationships, Weber lays the foundation for the decisive step towards analyzing the social in terms of opening and closing of social relationships. In doing so, he differentiates in a first step between "closure to the outside" and "closure within":

A social relationship (irrespective of whether communal relationship or associative relationship) will be spoken of as 'open' to the outside if and insofar on the ground of their current orders nobody, who is both able and apt to do so, is rejected from participating in the mutual social action that is oriented at a specific meaning. In contrast however, a relationship will be called 'closed' insofar and to the degree as either their meaning or their current social orders exclude, limit or attach conditions to participation (Weber [1922] 1985: 23, translation by J. Mackert based on Weber [1922] 1978: 43).

Defined this way, closure to the outside does not exclusively point to entirely excluding social actors or social sites from struggles for monopolized goods. Rather, "both the degree and the means of regulation and closure to the outside can vary, so that the transition from openness to being regulated and being closed is fluid" (Weber [1922] 1985: 24, translation by J. Mackert based on Weber [1922] 1978: 45). A huge variety of criteria can account for regulating access to or closing social relationships completely. Referring to the introductory examples of exclusion 
in today's world, we might think of the status as citizen or being a migrant, belonging to a specific social, cultural or political group or being poor, being LGBTQ or member of an indigenous people, and so forth. In all these cases degrees of regulation and closure to the outside may vary. Thus, Weber defines regulation and closure as "relative terms" (Weber [1922] 1978: 45).

Further, Weber defines closure within as closure among a certain group's members that may also take the most varied forms. Any kind of closed social relationship can guarantee monopolized chances to its members in different ways: Either "a) free to competition among the members; b) in a regulated or rationed way; or c) appropriated by individuals or sub-groups on a permanent basis and relatively or completely inalienable" (Weber [1922] 1985: 23, translation by J. Mackert based on Weber [1922] 1978: 44). Therefore, also within social relationships members might profit from goods, resources, or rights in at times extremely varying degrees.

From the perspective of social struggles, referring to all kinds of social relationships, be it communal or associative, and in pointing to varying degrees of their being closed, Weber without any doubt laid the foundation for a sociological perspective on the varieties and variabilities of strategies of social closure. However, Weber fell short of explaining what enables social groups to participate in closure struggles. I argue that Weber's explanation is unsatisfying because of his perspective of methodological individualism, obviously taking for granted that members of a common economic status would end up uniformly pursuing the same strategies towards others because of a shared style of life, conception of honor, connubium and commensality (Tilly 2005: 614). In addition to the lack of convincibility of this individualistic perspective with regard to powerful social groups enacting strategies of social closure, Weber was not interested at all in those confronted with social closure but only mentioned that the excluded might act against their being excluded (Weber [1922] 1978: 342) without elaborating on this perspective conceptually or analyzing this critical aspect in his empirical analyses.

Unfortunately, these critical problems have not been solved in the theory of social closure that in the 1970s and 80s took up the almost forgotten Weberian idea of social closure (Parkin 1974, 1979; Murphy 1988). Rather, they have been recycled like old wine in new skins.

\section{Problems in the Theory of Social Closure}

The theory of social closure deserves credit for having taken up Weber's approach. However, from the very beginning it was used in a narrow sense as a theoretical concept that might allow to supersede the limitations of then dominant class analysis. Especially Frank Parkin (1974, 1979) argued that to concentrate exclusively on inter-class relations would not do justice to the pluralist relations within social classes (intra-class relations) of modern society's complex social relations. Thus, he argued in favor of conceiving of social closure as a kind of social struggle among not only classes but also all social groups within society. In conceptualizing these social struggles, Parkin suggested to take up Weber's concept of social closure, arguing that "by social closure Weber means the process by which social collectivities seek to maximize rewards by restricting access to resources and opportunities to a limited circle of eligibles" (Parkin 1979: 44). Raymond Murphy (1988), in his Theory of Monopolization and Exclusion, followed this interpretation. In doing so, they both intensified the path Weber had taken by concentrating on 
processes of a monopolization of rights, resources and other goods, which then resulted in labeling the theory of social closure as a monopolization paradigm (Silver 1994), as I mentioned above.

However, Parkin and Murphy also tried to overcome Weber's shortcoming with regard to including the excluded in their approaches as they argued in favor of systematically taking these social actors, groups etc. and the specificity of their action strategies into consideration. Unfortunately, they managed to do so only to a certain extent. Parkin argued in favor of defining strategies of the powerful as exclusionary and the strategies of the weaker as usurpationary. Given that the capitalist state backed the powerful by means of the legal system and specific laws in order to legitimize exclusionary strategies of the propertied class, the consequent de-legitimization of the usurpationary strategies of excluded social actors left them only one option the so-called solidarization of the weak (Mackert 1999). Thus, usurpationary closure

tends to rely heavily upon the public mobilization of members and supporters, as in the use of strikes, demonstrations, sit-ins, marches, picketing, symbolic vigils, and the like. As a result, usurpationary activities normally stand in an uncomfortable relationship to the legal order. The borderline between lawful and unlawful usurpationary acts is often rather finely drawn, and tends moreover continuously to be redrawn over time, as chequered history of the right to strike and to 'peaceful picketing' well illustrates (Parkin 1979: 74-75).

All these strategies of course presuppose processes of the creation of social groups to be able to act collectively. However, Parkin did not engage in discussing these processes but seemed to take solidarity among the excluded for granted. Moreover Murphy, claiming to develop further Weber's approach and to supersede Parkin's elaborations, also failed in this regard. In presenting a structuralist model of rules and forms of exclusion he not only hardly mentioned conceivable counterstrategies of the excluded but seemed to take such strategies as being the effect of a given economic structure or the capitalist system. ${ }^{6}$ Neither Parkin nor Murphy explained what solidarity and solidarism actually meant but implicitly referred to a concept that sees solidarity as emerging from class position, consequentially leading to political struggle against exploitation.

Thus, the tradition of closure theory is hardly of any help if we want to understand and explain the common action of social actors in closure struggles. On the one hand, with regard to social groups pursuing strategies of social closure, neither Weber's individualistic perspective of taking it for granted because of a common social-economic status nor the structuralist/systemic perspective of the theory of social closure, viewing it as a structural or systemic effect of the capitalist system, give convincing explanations of collective action. On the other hand, neglecting the less powerful in closure struggles by either disregarding them, as Weber did, or by conceiving of solidarization as counterstrategy simply as a functional necessity reveals a serious problem in closure theory. Therefore, instead of sticking to an unclear concept of solidarity, we need to understand what allows social actors to develop collective strategies that we then might interpret as acting in solidarity. To be able to do so, we have to take a closer look at this problem in closure theory.

${ }^{6}$ I cannot go into detail about Murphy's structuralist and systemic approach here; see Murphy 1984. 


\section{A Critical Lacuna in Closure Theory: Group Formation}

While it is evident that both Weber and the theory of social closure deal with collective actors, in an illuminating analysis Heinz Steinert has attested to both approaches a general problem with regard to group action. Taking up insights of the theory of collective action (Olson 1965; Jordan 1996) he points to the important fact that closure means the procedure of organising an interest as the very precondition of conflict ability, i.e., the possibility of plausibly threatening to refuse a necessary service or good (cf. Steinert 2004: 199) or to fight back. This crucial aspect of organizing points to "processes of solidarism in order to develop a position in collective bargaining" (Steinert 2004: 200, translation by J. Mackert). ${ }^{7}$ What is at stake here is the simple fact that to be able to fight in closure struggles of daily life, social groups first of all have to be able to draw boundaries, thereby developing a political identity and closing their community. Thus, we have to address two questions: first, how can we properly understand these processes that allow for social groups to develop conflict ability? Second, how can we understand why these processes fail and social groups do not succeed in doing so? To answer these questions and in contrast to the state of the art of closure theory briefly outlined above, I argue that neither the individualistic and structuralist/systemic methodologies nor an utterly unclear conception of solidarity or solidarism are of any help. Rather, I suggest taking a relational methodological perspective to make comprehensible how collective political identities occur. By taking up critical insights of Gertrude Neuwirth's contribution I will point to the direction of how closure theory needs to be revised with regard to the problem of this article.

\section{The relational perspective: Considering political identities}

Taking Weber's perspective on social life as struggle seriously and adopting a relational methodological perspective on social closure enables us to ask a new set of questions: In closure struggles, who are those in powerful positions, able to enact closure strategies that inevitably compromise the life chances of those affected by them? Who are those in weaker positions, confronted with the impact of that social closure, i.e., being exploited, disenfranchised, marginalized and repressed? In closure struggles social actors simply ask, "Who are we?" and "Who are they?", which means that by drawing a line between Us and Them (Tilly 2003), social actors turn capable of developing a conception of themselves that allows them to act collectively. Rather than assuming already existing collective social actors that in social closure struggles start to interact, as both Weber and the theory of social closure for various methodological reasons did, following Charles Tilly's relational view allows for understanding how, in permanent social interaction of both parties, collective identities emerge that become critical in closure struggles:

Identities belong to that potent set of social arrangements in which people construct shared stories about who they are, how they are connected, and what has happened

\footnotetext{
${ }^{7}$ With regard to his historical examples, Steinert argues that Weber misses the categorical difference between monopolisation and solidarism. "Land is a resource existing independently from closure - professional licenses become a resource only by creating associations (and protection by the state). In one case a resource is monopolised by being appropriated, in the other case the resource is created only by solidarism" (Steinert 2004: 199, translation by J. Mackert).
} 
to them. Such stories range from the small-scale production of excuses, explanations, and apologies when something goes wrong to the large-scale production of peace-settlements and national histories (Tilly 2003: 608).

In the midst of these small-scale and historical, large-scale events we can locate the process of creation of collective identities in closure struggles that we can define as political identities, given that in all closure struggles outlined above, governments play a critical role (Tilly 2003: 609). ${ }^{8}$ More precisely, from this perspective, we can distinguish four aspects of identities: " 1 ) a boundary separating me from you or us from them; 2) a set of relations within the boundary; 3 ) a set of relations across the boundary; 4) a set of stories about the boundary and the relations" (Tilly 2003: 608). ${ }^{9}$

That collective identities are constructed by social actors on both sides of the boundary telling stories about who they and the others are becomes obvious if we take seriously that both parties in closure struggles ask the critical question of who they are. From this methodological perspective, the plurality of social relations is expressed in various stories - about the boundary, about one's own group ("Who are we?"), about the other group ("Who are they?"); and finally, there are common stories told on both sides. That opens a perspective to understand how by drawing boundaries social actors develop their collective identities, because "identities reside in relations" (Tilly 2005: 8), and that allows them to turn to group action.

\section{A critical void: Strategies preventing the closure of a community}

While a relational approach explains how social actors develop political identities enabling them to act as collective actors, it also allows to understand why not all social groups are able to do so. Social groups may be unable to draw boundaries to develop a sense of who they are, the consequence being that they are unable to succeed in closing their community and therefore remain vulnerable to closure attacks. Neither Weber nor the theory of social closure have paid attention to this critical aspect of closure struggles as all of them concentrated on discussing social closure as exclusion in order to monopolize certain resources. Therefore, the equally important aspect of the less powerful sites' efforts to close their own community went unnoticed.

This theoretical void is all the more surprising because of Gertrude Neuwirth's lucid analysis in A Weberian Outline of a Theory of Community: Its Application to the 'Dark Ghetto'. As early as 1969 she made explicit the consequences for a less powerful social group if its community closure fails because of both given social and cultural conditions as well as interventions by the powerful. She highlights the consequences of political, economic, and cultural strategies of the

\footnotetext{
${ }^{8}$ To have stressed the role the state plays in closure struggles is one of Parkin's important contributions to closure theory.

${ }^{9}$ Charles Tilly's approach is highly informative as it offers a unique approach to understanding in the tradition of Frederik Barth (1969). Looking at how collective identities arise from this constructivist perspective has also been stressed by Andrew Abbott (1995) in his Things of Boundaries, while single aspects of Tilly's approach have been prominent in various debates. Regarding boundaries, see Lamont \& Molnár (2002); regarding symbolic struggles, see Bourdieu (1979); regarding questions of identity in processes of exclusion, see Scotson \& Elias (1996), Alexander \& Smith (1993); for various aspects and forms of community building, see Somers (2008), Brubaker (2004), Wimmer (2008).
} 
White that make it impossible for the Black community to achieve community closure, which effectively prevents them from overcoming their subordinated position (Neuwirth 1969: 151).

First, Neuwirth argues that "[closure] by dominant communities may be so effectively directed against certain groups that these group members are unable to resort to their own community formation and closure in order to improve their under-privileged position" (Neuwirth 1969: 151). Closure therefore is not simply a strategy to block others from access to a certain good or resource but also a strategy that hinders the less privileged from becoming capable of acting at all. In this sense, closure is a strategy of dominant groups to prevent the formation of a community that would possibly become a powerful actor in social closure struggles. Second, if this is the case, then a social group's "inability to achieve closure leaves it as a 'negatively privileged' with regard to (1) the denial of economic and political opportunities and (2) the denial of social esteem" (Neuwirth 1969: 152). While the first of these aspects refers to the possibility of monopolising resources and blocking access to them, the second introduces dignity and esteem as critical aspects into closure analysis. Third, Neuwirth points to two critical consequences of the "vulnerability implicit in negatively privileged status. The denial of economic and political opportunities prevents these individuals from influencing the terms of their participation in the larger society" (Neuwirth 1969: 152). The first consequence is obvious as it points to the exclusion from social, economic, cultural and political life of social actors with a negatively privileged status. Yet, the second aspect radicalises this process of closure:

Moreover, representatives of the dominant communities will regulate those affairs and interests of the negatively privileged which, if left uncontrolled, might affect the interests and relative positions of the dominant communities within the larger society. By this process, representatives of the dominant communities prevent any attempts of community closure by the negatively privileged (Neuwirth 1969: 152). ${ }^{10}$

However, Neuwirth goes even one step further, showing how historical, social and political conditions are important to understand why a specific group is not able to close its community. She argues that such a critical situation enables powerful groups to pursue closure strategies that only aggravate it. In the case of American Blacks, she remarks that there are the given conditions creating facts,

suggesting that urban Negroes not only are unable to bring about community closure, but also that in reality they are prevented from achieving it by the white community. Establishing support for both of these assertions involves a functionally related point of view: the inability to effect closure is not only the result of certain historical and contemporary conditions concerning the Negroes' position within the larger society,

\footnotetext{
${ }^{10}$ While conceptual and theoretical reflection of closure theory so far has disregarded this pivotal aspect of social closure, recently two studies have followed Neuwirth's perspective and made clear the crucial significance of this impact of the strategies of the powerful on the less powerful. Eddie Hartmann's $(2011,2017)$ analysis that revealed these complex processes in the case of young people, mainly descendants of migrants from former French colonies in Central Africa and the Maghreb living in the banlieues of French cities. In a more recent analysis of the European refugee and asylum administration, Max O. Schmidt (2021) has also stressed strategies of closure that aim at preventing processes of solidarization not only among refugees but especially among refugees and local support groups or the granting of church asylum.
} 
but also in turn facilitates attempts by others to prevent such community closure (Neuwirth 1969: 153-154, emphasis added).

Moreover, making this critical point for closure theory even clearer:

The economic and social controls which representatives of society exert directly upon residents of the Dark Ghetto are further means to prevent community closure. They are forced to pay high rents for substandard housing; they are frequently over-charged for food and other household items; lacking knowledge and other opportunities, they may be charged with fraudulent interest rates for credit purchases. In their dealings with agencies of social control, such as the police, Negroes are exposed to different and discriminatory standards than are whites. These examples reflect rather obvious and deliberate attempts at preventing community closure. The white community also introduces other, subtler attempts, which officially, are designed to alleviate problems of the ghetto but which actually tend to perpetuate the Negroes' powerlessness. This applies particularly to the programmes initiated by the War Against Poverty (Neuwirth 1969: 157).

While this crucial quotation describes the situation of race segregation in the US at the height of the Civil Rights Movement, at the same time it reminds us of today's practices with regard to a number of seemingly normal processes under conditions of a neo-liberalised democracy with dismantled welfare institutions and a punitive state (Jones-Eversley, Adedoyin, Robinson \& Moore 2017). On the one hand, strategies such as racial profiling, surveillance of refugees, policing Muslims or minority groups, and mass incarceration are all ideologically justified with reference to security and terrorism. On the other hand, the control and pressuring of welfare recipients and punishing the poor are ideologically justified with social rights no longer being a right but people having to prove to be worthy of receiving assistance and being categorized as deserving poor.

From the perspective of social closure theory, all these strategies are simply aspects of a politics of social closure that deprives the respective social groups of resources and rights, perpetuating these groups' powerlessness, impinging on their creating solidarity, and aim at managing their lives.

\section{Towards a Reorientation of Social Closure}

Instead of working with an intrinsically unclear concept of solidarity in closure analyses that rest upon an individualistic or structuralist/systemic methodology, I argue in favor of approaching the analysis of social closure struggles from a relational perspective and to dispense with vague conceptions of solidarity or solidarism, since it is obvious that closure theory is fraught with problems when it comes to broaching the issue of solidarity. Therefore, at least three critical aspects need to be confronted:

First, neither on the side of the powerful enacting exclusionary strategies nor on the side of the less powerful can we simply take for granted any kind of collective action. As an indispensable precondition social groups or classes need to draw boundaries to close their community. Neither a common social status with a shared style of life (Weber) nor a common class position 
(Parkin, Murphy) necessarily and immediately generate solidarity among the powerful. There might be conflicting interests and struggles within the powerful that need to be taken into account, such as conflicting interests of fractions of capital. To be sure, the powerful have all the resources they need to act collectively and organize, and they have the backing of the law and support of the state. Yet closure analysis points to the necessity of explaining how these powerful groups succeed in closing their own community in relation to the less powerful rather than simply assuming it.

Second, while Weber did not pay attention to the action of the excluded in closure struggles but simply mentioned that they may possibly react to their being excluded, Frank Parkin assumed that the excluded groups have no option but to take up the strategy of solidarism. However, as I have argued, this does not happen necessarily; rather acting collectively presupposes highly complex and complicated social processes of being able to develop boundaries that allows less powerful groups to close their communities as the inevitable precondition to become a capable actor in closure struggles.

Third, taking this methodological perspective seriously and bringing it back into the center of social closure analysis - as Neuwirth has done at an early point of time - allows for broadening the supposedly narrow economic paradigm of monopolization and thereby to better analyze the manifold strategies of the powerful. If, following Weber, we conceive of social life as struggle, closure struggles are highly significant in understanding social life in general. Of course, analyzing strategies of the powerful that deny the less powerful access to rights, resources and further options to realize their life chances is crucial for social closure. However, taking seriously that strategies of social closure also target the less powerful and therefore vulnerable social groups themselves as they try to draw boundaries and close their communities is equally important and needs to be systematically considered in closure analyses.

In this sense, closure theory can serve as theoretical and analytical tool to investigate empirically why social groups that are confronted with strategies of social closure are able to close their communities and fight back or why this is not the case. Of course, taking up Weber's sociological differentiation, this may be possible to extremely varying degrees.

\section{Conclusion}

Coming back to the examples discussed in the beginning of this article, we might draw some conclusions that allow for a better understanding of how social groups react to their being excluded; why not all groups react and why, consequentially, not all of them seem to be able to develop collective counterstrategies.

Conceiving of social life as struggle, as Weber does, not only assigns the analysis of social closure and consequentially social closure struggles a prominent role from a socio-theoretical perspective but also contextualizes seemingly ossified conditions of being excluded within a processual perspective. Thus, rather than thinking statically, closure theory allows for thinking in processes of ongoing struggles being an ineradicable element of social life.

Such struggles become obvious in Neuwirth's early analysis of the Dark Ghetto in that cultural, economic and political White supremacy has made impossible the closing of the communities. However, ongoing closure struggles have led to organizing that has become obvious and 
powerful in the Black Lives Matter movement that supposedly started in 1994 with the brutal beating of Rodney King in Los Angeles and that today fights back both exclusion and the impact of White supremacy on Black communities (Camp \& Heatherton 2016). This perspective allows for understanding the strength of power asymmetries in closure struggles as fundamental dynamics of social life, but it also makes obvious that closure analysis needs to take into account the changing conditions of a politics of social closure, regardless if these conditions change to the better or worse.

Thus, the idea of struggle as social life points to the necessity to take a dynamic view on these struggles. Bringing back Neuwirth's perspective not only shows how changing social and cultural conditions and closure strategies mutually reinforce and impinge on a social groups' possibilities to organize and mobilize but at the same time stresses such a group's vulnerability and makes comprehensible how strategies of closure threaten their dignity, which enriches social closure analysis and makes it more comprehensive. In this sense, the Black Lives Matter movement may be an example of successfully fighting back both aspects of social closure, which of course does not mean that it will succeed in the end. Yet, it attacks the social, political and economic conditions of Black lives in the US while at the same time fighting back police brutality, incarceration, social deprivation and so forth, which are all single aspects of a politics of closure aiming at keeping the Black community in an underprivileged and subordinate situation.

The case of Palestinian Lives Matter shows the reverse. Without a comparatively strong support from outside, Palestinians are exposed to a brutal occupation regime that not only excludes them from access to such basic resources as water or electricity but also from any basic citizenship rights. Further, following the "logic of elimination" (Wolfe 2006; Pappe 2006), ${ }^{11}$ like any other settler colonial society (Baumgarten 2021; Khalidi 2020; Masalha 2018; Veracini, 2013; Salamanca et al. 2012) the Zionist regime, ${ }^{12}$ with the help of the Palestinian Authority (Burkert 2021; Dana 2021), ${ }^{13}$ represses any civil society movement, imprisons people for cultural or po-

${ }^{11}$ In his seminal essay Settler Colonialism and the Elimination of the Native, Patrick Wolfe has argued that in all settler societies there is a logic of elimination that does not necessarily have to be genocidal. Thus "elimination refers to more than the summary liquidation of Indigenous people, though it includes that. In its positive aspect, the logic of elimination marks a return whereby the native repressed continues to structure settler-colonial society. It is both as complex social formation and as continuity through time that I term settler colonization a structure rather than an event, and it is on this basis that I shall consider its relationship to genocide" (Wolfe 2006: 390).

${ }^{12}$ Zionism as a radical nationalist ideology has been developed by Theodor Herzl in The Jewish State as early as in 1896, expressing today's self-conception of the state of Israel. Herzl argued in favor of Jews settling in Palestine, making a strong argument in favor of White supremacism by drawing a clear distinction between the Judeo-Christian "civilization" and the non-White Barbarians: "We should there form a portion of a rampart of Europe against Asia, an outpost of civilization as opposed to barbarism [emphasis added]. We should as a neutral State remain in contact with all Europe, which would have to guarantee our existence. The sanctuaries of Christendom would be safeguarded by assigning to them an extra-territorial status such as is well-known to the law of nations" (Herzl [1896] 1946).

${ }^{13}$ From the perspective of closure theory, it would be interesting to analyze the Palestinian Authority's (PA) strategies towards Israel and the Palestinians as an expression of what Frank Parkin (1979) has called dual closure, assuming that the PA aims at usurping power and privileges from the excluding Israeli side while excluding the masses of Palestinians from basic resources and support, thereby employing both strategies of social closure, i.e., exclusion and usurpation. However, it seems more convincing to analyze the PA's strategies as fulfilling Israel's demands while having established a crony capitalism that is "a defining feature of the PA's relations with a handful of capitalists and business groups. [...] In the Occupied Palestinian 
litical activities, puts them in administrative detention or secret prisons, torturing and even killing them. There is hardly a more radical and more violent way to prevent a social group from closing its community and prevent it from becoming a collective social actor who can fight back closure than the strategies pursued in the daily atrocities, such as arbitrary detentions, the expulsion of communities, imprisonment of minors, separating families and many more, that are pursued to destroy the Palestinian community (for documentation of such practices, see B’Tselem, n.d.).

A closure concept that also takes into consideration the preconditions of social groups to close their communities and turn into collective actors in closure struggle will no longer restrict itself to analyzing the exclusion from rights and resources and the way they are monopolized by the powerful. Rather, it will allow to understand the dynamics of ongoing social closure struggles in order to a) monopolize rights, resources and so forth; b) the strategies of the powerful to impinge on the communities of the less powerful; c) the specific conditions of the less powerful; and d) the different possibilities of the less powerful to organize and develop counterstrategies. This is true from the indigenous peoples in Brazil to the Algerian people in the hirak, who succeed in parts to fight back, to the poor and homeless in the center of neoliberal capitalism, who do not. Revising closure theory will make it the most promising theoretical approach to analyze and explain today's struggles for democracy and participation, and even the struggles for survival all over the world.

\section{Acknowledgements}

The author is grateful to the anonymous reviewers and the editors of socialpolicy.ch for helpful comments and feedback.

\section{Declaration of conflicting interests}

The author declared no potential conflicts of interest with respect to the research, authorship, and/or publication of this article.

\section{Funding}

The author did not receive any financial support for the research, authorship, and/or publication of this article.

Territories, crony capitalism was developed as part of the political allegiances and economic alliances that underpin the structures created by the Oslo process, which are fostered by Israeli policies and the international donor community to maintain the cohesiveness of the PA regime" (Dana 2019: 247). 


\section{References}

Abbott, Andrew (1995). Things of Boundaries. Defining the Boundaries of Sociological Inquiry. Social Research: An International Quarterly, 63(1), 857-882.

Abellan Matamoros, Christina (2019). Forced labour most prevalent form of modern slavery in Europe, says report. Last accessed 24.04.2021 on https://www.euronews.com/2019/07/17/forced-labourmost-prevalent-form-of-modern-slavery-in-europe-says-report.

AFP (2021). Third night of protests in Poland after abortion ban takes effect. The Guardian, January 29. Last accessed 24.04.2021 on https:/www.theguardian.com/world/2021/jan/29/third-night-of-protests-in-poland-after-abortion-ban-takes-effect.

Ahmed, Kaamil (2020). EU accused of abandoning migrants to the sea with shift to drone surveillance. The Guardian, October 28. Last accessed 24.04.2021 on https://www.theguardian.com/global-development/2020/oct/28/eu-accused-of-abandoning-migrants-to-the-sea-with-shift-to-drone-surveillance.

Alexander, Jeffrey C. and Philip Smith (1993). The Discourse of American Civil Society: A New Proposal for Cultural Studies. Theory and Society, 22(2), 151-207.

Barth, Frederik (1969). Introduction. In: Barth Frederik (Ed.), Ethnic Groups and Boundaries: The Social Organization of Cultural Differences. Boston: Little, Brown, 9-38.

Baumgarten, Helga (2021). The struggle for democratic space under violent settler colonialism and authoritarian rule. In: Mackert, Jürgen, Hannah Wolf and Bryan S. Turner (Eds.), The Condition of Citizenship. Vol. 3. Postcolonial and Settler-colonial Contexts. London: Routledge, 90-109.

Bourdieu, Pierre (1979). Distinction: A Social Critique of the Judgement of Taste. London: Routledge and Kegan Paul.

Bracken, Amber (2020). Canada: Protests go mainstream as support for Wet'suwet'en pipeline fight widens. The Guardian, February 14. Last accessed 24.04.2021 on https://www.theguardian.com/world/2020/feb/14/wetsuweten-coastal-gaslink-pipeline-allies.

Brubaker, Rogers (2004). Ethnicity without Groups. Cambridge: Harvard University Press.

B'Tselem (The Israeli Human Rights Center for Human Rights in the Occupied Territories). Last accessed 24.04.2021 on https://www.btselem.org/.

Burkert, Rebecca (2021). Moving mountains? Palestinian claim-making from Oslo onwards. In: Mackert, Jürgen, Hannah Wolf and Bryan S. Turner (Eds.), The Condition of Citizenship. Vol. 3. Postcolonial and Settler-colonial Contexts. London: Routledge, 110-127.

Camp, Jordan T. and Christina Heatherton (Eds.) (2016). Policing the Planet. Why the Policing Crisis led to Black Lives Matter. London: Verso.

Chomsky, Noam (1999). Profit over People. Neoliberalism and Global Order. New York: Seven Stories Press.

Dana, Tariq (2019). Crony Capitalism in the Palestinian Authority: A Deal among Friends. Third World Quarterly, 41(2), 247-263.

Dana, Tariq (2021). Israeli conception of 'peace' as indirect colonial rule. In: Mackert, Jürgen, Hannah Wolf and Bryan S. Turner (Eds.), The Condition of Citizenship. Vol. 3. Postcolonial and Settler-colonial Contexts. London: Routledge, 71-89. 
De Pablo, Ofelia, Pablo Zurita, Annie Kelly and Clare Carlile (2020). ,We pick your food'. Migrant workers speak out from Spain's ,Plastic Sea'. The Guardian, September 20. Last accessed 24.04.2021 on https://www.theguardian.com/global-development/2020/sep/20/we-pick-your-food-migrantworkers-speak-out-from-spains-plastic-sea.

DW (Deutsche Welle) (2021). Russia: Mass arrests as Alexei Navanly supporters defy protest ban. January 21. Last accessed 24.04.2021 on https://www.dw.com/en/russia-mass-arrests-as-alexei-navalny-supporters-defy-protest-ban/a-56394521.

Fallon, Katy (2021). EU announces funding for five new refugee camps on Greek islands. The Guardian, March 29. Last accessed 24.04.2021 on https://www.theguardian.com/global-development/2021/mar/29/eu-announces-funding-for-five-new-refugee-camps-on-greek-islands.

Hartmann, Eddie (2011). Strategien des Gegenhandelns. Zur Soziodynamik symbolischer Kämpfe um Zugehörigkeit. Konstanz: UVK.

Hartmann, Eddie (2017). In the Zone of Spoiled Civil Identity: The Riots in Suburban France in 2005. In: Mackert Jürgen and Bryan S. Turner (Eds.), The Transformation of Citizenship. Vol. 3. Struggle, Resistance and Violence. London: Routledge, 39-55.

Herzl, T. [1896] (1946). The Jewish State. Last accessed 24.04.2021on https://www.jewishvirtuallibrary.org/quot-the-jewish-state-quot-theodor-herzl.

Jones-Eversley, Sharon, A. Christson Adedoyin, Michal A. Robinson and Sharon E. Moore (2017). Protesting Black inequality: A commentary on the civil rights movement and Black lives matter. Journal of Community Practice, 25(3-4), 309-324.

Jordan, Bill (1996). A Theory of Poverty and Social Exclusion. Cambridge: Polity Press.

Khalidi, Rashid (2020). The Hundred Year War on Palestine: A History of Settler Colonial Conquest and Resistance, 1917-2017. New York: Metropolitan Books

Lamont, Michèle and Virág Molnár (2002). The Study of Boundaries in the Social Sciences. Annual Review of Sociology, 28, 167-195.

Langer, Marie-Astrid (2020). Kanada: Ureinwohner blockieren Schienenverkehr. Neue Züricher Zeitung. Last accessed 24.04.2021 on https://www.nzz.ch/international/kanada-ureinwohner-blockieren-schienenverkehr-ld.1541105.

Losurdo, Domenico (2014). Liberalism. A Counter-History. London: Verso.

Lloyd, David (2012). Settler Colonialism and the State of Exception: The Example of Palestine/Israel. Settler Colonial Studies, 2(1), 59-80.

Loyd, Jeanna M. and Bonds, Anne (2018). Where do Black lives matter? Race, stigma, and place in Milwaukee, Wisconsin. The Sociological Review, 66(4), 898-918.

Mackert, Jürgen (1999). Kampf um Zugehörigkeit. Nationale Staatsbürgerschaft als Modus sozialer Schließung. Opladen: Westdeutscher Verlag.

Mackert, Jürgen (2012). Social Closure. In: Jeff Manza (Ed.), Oxford Bibliographies Online. Oxford: Oxford University Press.

Mackert, Jürgen (2021). Introduction. A 'Master-Race Democracy': Myths and Lies of Western Civilization. In: Jürgen Mackert, Hannah Wolf and Bryan S. Turner (Eds.), The Condition of Democracy. Vol. 3. Postcolonial and Settler Colonial Contexts. London: Routledge, 1-13. 
Mamdani, Mahmood (2015). Settler Colonialism: Then and Now. Critical Inquiry, 41(3), 596-614.

Mann, Michael (2005). The Dark Side of Democracy. Explaining Ethnic Cleansing. Cambridge: Cambridge University Press.

Masalha, Nur (2018). Palestine. A Four Thousand Year History. London: ZED Books.

Masarwa, Lubna and Dana Akkad (2017). Israeli court extends Palestinian MP's detention by another six months. Middle East Eye, December 27. Last accessed 24.04.2021 on https://www.middleeasteye.net/news/israeli-court-extends-palestinian-mps-detention-another-six-months.

Mills, Charles W. (1997). The Racial Contract. Ithaca: Cornell University Press.

Müller, Hans-Peter (2007). Max Weber. Eine Einführung in sein Werk. Köln, Weimar und Wien: Böhlau Verlag. UTB.

Muaddi, Qassam (2021). Palestinian Authority's push to regulate NGOs raises fear of power grab. Middle East Eye, March 3. Last accessed 24.04.2021 on https://www.middleeasteye.net/news/abbas-newlaw-will-turn-palestinian-nonprofits-government-agencies-according-palestinian-ngos.

Murphy, Raymond (1988). Social Closure: The Theory of Monopolization and Exclusion. Oxford: Clarendon Press.

Neuwirth, Gertrud (1969). A Weberian Outline of a Theory of Community: Its Application to the "Dark Ghetto”. British Journal of Sociology, 20(2), 148-163.

Northey, Jessica, A. (2021). The Algerian hirak - Civil Society, Non-violence and the New Movement for Democracy. In: Mackert Jürgen, Hannah Wolf and Bryan S. Turner (Eds.), The Condition of Citizenship. Vol. 3. Postcolonial and Settler-colonial Contexts. London: Routledge, 17-32.

Olson, Mancur (1965). The Logic of Collective Action. Public Goods and the Theory of Groups. Cambridge: Harvard University Press.

Pappe, Ilan (2006). The Ethnic Cleansing of Palestine. London: Oneworld Publication.

Parkin, Frank (1974). Strategies of Social Closure in Class Formation. In: Frank Parkin (Ed.), The Social Analysis of Class Structure. London: Tavistock, 1-18.

Parkin, Frank (1979). Marxism and Class Theory: A Bourgeois Critique. New York: Columbia University Press.

Patterson, Orlando and Xiaolin Zhuo (2018). Modern Trafficking, Slavery, and Other Forms of Servitude. Annual Review of Sociology, 44, 407-439.

Plaut, Martin (2017). Europe's crackdown on African immigration is hitting vulnerable refugees. The Guardian, January, 26. Last accessed 24.04.2021 on https://www.theguardian.com/commentisfree/2017/jan/26/europe-crackdown-africa-immigration-vulnerable-refugees-sudan-eritrea.

Roth, Kenneth (2020). China is desperate to stop Hong Kong's pro-democracy movement. Human Rights Watch, August 19. Last accessed 24.04.2021 on https://www.hrw.org/news/2020/08/19/chinadesperate-stop-hong-kongs-pro-democracy-movement\#.

Salamanca, Omar Jabari, Mezna Qato, Kareem Rabie and Sobhi Samour (2012). Past is present: settler colonialism in Palestine. Settler Colonial Studies, 2(1), 1-8.

Schmidt, Max O. (2021). Seenotrettung und Kirchenasyl. Organisationale Schließungskämpfe im Feld der europäischen Asylverwaltung. Wiesbaden: Verlag für Sozialwissenschaften. 
Scotson, John L. and Norbert Elias (1994). The Established and the Outsiders: A Sociological Enquiry into Community Problems. London and Thousand Oaks: Sage.

Silver, Hilary (1994). Social Exclusion and Social Solidarity. Three Paradigms. International Labour Review, 5-6(133), 531-578.

Somers, Margaret R. (2008). Genealogies of Citizenship: Markets, Statelessness, and The Right to Have Rights. Cambridge: Cambridge University Press.

Stein, B. (2006). In Class Warfare guess which Class is Winning. Last accessed 24.04.2021 on https://www.nytimes.com/2006/11/26/business/yourmoney/26every.html.

Steinert, Heinz (2004). Schließung und Ausschließung. Eine Typologie der Schließungen und ihrer Folgen. In Jürgen Mackert (Ed.), Die Theorie sozialer Schließung. Tradition, Analysen, Perspektiven (pp. 193-212). Wiesbaden: Verlag für Sozialwissenschaften.

Tilly, Charles (2003). Political Identities in Changing Polities. Social Research, 70(2), 605-620.

Tilly, Charles (2004). Social Boundary Mechanisms. Philosophy of the Social Sciences, 34(2), 211-236.

Tilly, Charles (2005). Identities, Boundaries and Social Ties. Boulder: Paradigm.

Veracini, Lorenzo (2013). The Other Shift: Settler Colonialism, Israel, and the Occupation. Journal of Palestine Studies, 24(2), 26-42.

Weber, Max [1922] (1978). Economy and Society. An Outline of Interpretive Sociology. Edited by Guenther Roth \& Claus Wittich. Berkeley, Los Angeles and London: University of California Press.

Weber, Max [1922] (2012). The Meaning of 'Value Freedom' in the Sociological and Economic Sciences (pp. 304-334). In: Max Weber, Collected Methodological Writings. Edited by Henrik H. Bruun \& Sam Whimster. London and New York: Routledge.

Wimmer, Andreas (2008). The Making and Unmaking of Ethnic Boundaries: A Multilevel Process Theory. American Journal of Sociology, 113(4), 970-1022.

World Bank (2020). Covid-19 to add as many as 150 Million extreme poor by 2021. October 7. Last accessed 24.04.2021 on https://www.worldbank.org/en/news/press-release/2020/10/07/covid-19-toadd-as-many-as-150-million-extreme-poor-by-2021. 